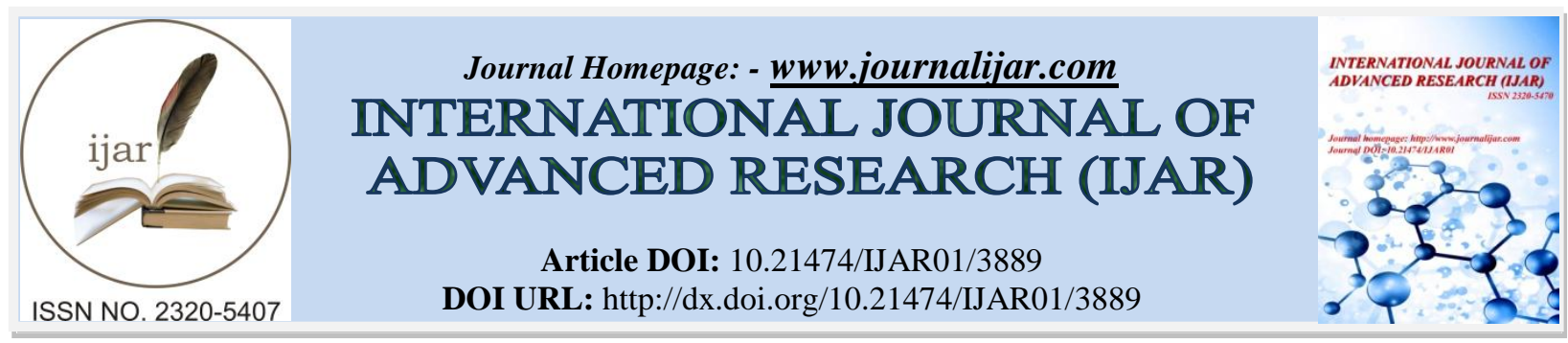

RESEARCH ARTICLE

\title{
ISOLATION AND CHARACTERIZATION OF LACTIC ACID BACTERIA FOR PROBIOTIC APPLICATION FROM PLANT SOURCES.
}

Koppula Prawan and Bhukya Bhima*.

Department of Microbiology, University College of Science, Osmania University, Hyderabad-500007, Telangana, India.

\section{Manuscript Info}

\section{Manuscript History}

Received: 09 February 2017

Final Accepted: 07 March 2017

Published: April 2017

Key words:-

Antimicrobial, Antibiotic Susceptibility, Probiotics, LAB, Phenotypic.

\begin{abstract}
Live microorganisms, have beneficial effects on their host's health, are called as Probiotics. As the Probiotics play an important role in ensuring the food security of millions of people around the world, particularly marginalized and vulnerable groups. This can be achieved by increasing the range of raw materials that can be used to produce edible food products and removing anti- nutritional factors to make food safe and rich with nutritional value as a supplement to eat. Generally the Plant sources for lactic acid bacteria (LAB) were isolated from spoiled vegetables, Fruits and kitchen waste. In order to identify the predominating Lactic acid bacteria (LAB) organisms from these sources, the phenotypic characteristics morphological and biochemical tests of these strains were determined with respect to potential Probiotics properties. Thus, an investigation was carried out to isolate and characterize a potential Probiotic LAB from this isolates. The antibiotic susceptibility and antimicrobial tests were performed to check the Probiotic potentials. Some of the isolates showed potential as a Probiotic owing to its antibiotic sensitivity, antimicrobial potential and ability to survive under acidic environment.
\end{abstract}

Copy Right, IJAR, 2017,. All rights reserved.

\section{Introduction:-}

Plant sources like vegetables and Fermenting fruits can bring many benefits Specially to the people in Third world countries as it is naturally available source and also affordable . Lactic acid bacteria (LAB) are the most common types of microbes used as Probiotics (Herich and Levkut, 2002), as food occurs in diverse forms comprising mainly of fruits, cereal products, vegetables, milk products, meat products and many other related products. The food here is significant because today newer trends in food diversification for value addition are being looked into. The beneficial effects of Probiotics is not only enhances the host body by helping in maintenance, promotion of health and most importantly in the reduction of pathogenic diseases. As this are being worked out from food products may be fermented vegetable, fruit, cereal products or Dairy products based on the consumption. As we are observing the latest trend is more than survival today over more emphasis is towards healthy diet. Food sciences at different labs around the world are developing foods which promote good health and reduce risk of major diseases one such food product which is being used by scientists is Probiotic. Putting lot of efforts to bring Probiotic products into the market and these are identified as functional foods. Lactic acid bacteria are very good sources in Probiotics having potential properties to boost the health, when administrated in adequate amounts, confer health benefit on the host. As this is one of the multi million Euro businesses in the market. The desirable Robotics should have the following 
properties: resistance to acid and bile toxicity, adherence to human intestinal cells, gut micro flora colonization , antagonism against pathogenic bacteria, production of antimicrobial substances, and immune modulation properties.(salminen et al 1996) Lactic acid bacteria are regarded to be one of the major group of Probiotic bacteria(Collins et al Tannock ) It's been from ancient times and till date in some cultures it's been practiced . Metchnikoff in 1908 suggested that, the healthy life of Bulgarian peasant's results from the consumption of fermented milk products. The harmful effects of antibiotics add beneficial effects of LAB were explained by vergin. According to the Ouwehand et al Probiotics are non pathogenic microorganisms that when ingested in certain numbers impart a positive influence on the physiology of the host and its health beyond inherent general nutrition. Probiotics is known to help in the balancing normal intestinal micro flora. Lactic acid bacteria are present in foods (dairy products, sour dough, fermented meat, fermented vegetables, silage, beverages), in sewage, on plants, as well as within the genital, intestinal and respiratory tracts of humans and animals Lactic acid bacteria from different sources (dairy, meat, plant products, and traditional fermented products) The mechanism of action of Probiotics with anti-microbial properties is maybe due to the production of bacteriocins such as niacin [1] lor lowering the $\mathrm{pH}$ by producing acidic compounds like lactic acid, [2]. Probiotic strains compete with other infectious bacteria for nutrients and cell-surface and help toward them off by inhibiting their colonization [3]. A few strains are also known to produce active enzymes which inhibit other pathogenic bacteria [4]. The health benefits of Probiotics have always been investigated with regard to their capability to sustain their availability, viability [5], digestibility, and rendering of their health benefits to the host without altering the safety [6]

The present study was undertaken to screen out the potential LAB isolates producing bacteriocins from spoiled vegetables, fermented vegetables and fruits.

\section{Materials and Methods:- Sample collection:}

Spoiled Vegetable, vegetable peels from kitchen Wastes( Tomato, Potato, cabbage), fermented vegetable pickle (mango, tomato, cabbage, mixed vegetable pickle) and fruits (banana, pine apple, Mango) were collected from dump yard of a local market(Rythu bazaar, Monda market), Hotel kitchens at Secunderabad, ECIL, Osmania Campus region of Telangana, India. All the samples were transported to the Department of Microbiology, Osmania University, and Telengana under safe conditions, where further studies were performed.

\section{Isolation of Lactic Acid Bacteria:-}

The collected samples were subjected to tenfold serial dilution. The lactic acid bacteria were isolated on MRS (pH $6.8 \pm 0.02$ ) medium and incubated at $37^{\circ} \mathrm{C}$ for $24 \mathrm{hrs}$. The plates were observed for appearance of colonies and number of colonies produced on each plate. The lactic acid bacteria were maintained freshly throughout the experimental work. Bacteria were purified by streak plate method on MRS agar and incubated at $37^{\circ} \mathrm{C}$ for $24 \mathrm{hrs}$ and transferred to MRS agar slants and then maintained in refrigerator at $4^{0} \mathrm{C}$ till further analysis.

\section{Identification of Isolated strains:-}

The different pure cultures so obtained were characterized for their colony morphology and subjected to Gram staining, endospore staining, catalase test, carbohydrates fermentation test according to Holt et al. (7) Only Gram positive, non-motile, rod shaped bacteria, showing phenotypic characters similar to Lactobacillus species on MRS agar media were selected for further experiments. The isolated bacterial strains were maintained properly through regular sub-culturing on MRS media. The fresh cultures were used throughout the experiments.

The identification of potent isolates up to species level was done based on the characteristics of Lactobacillus as described in Bergey's Manual of Systematic Bacteriology (Kandler, O. and N. Weis, eds. Regular Nonsporing Gram-Positive Rods. Bergey's Manual of Systematic Bacteriology. 2nd ed. Vol. IV. 2005, Springer. 1208-1231.). The cultures were subjected to a battery of biochemical tests which included fermentation of different carbon sources, acid and gas production from glucose, catalase test, Motility test, Bile tolerance test etc.

\section{Antibiotic sensitivity test:-}

The antibiotic susceptibility of isolated LAB was assessed using antibiotic discs diffusion method on MRS agar plates. Broth cultures of LAB was prepared using MRS and adjusted to 0.5 McFarland standards. The freshly grown overnight isolated Lactobacillus Spp. cultures were spread on MRS agar plates. The antibiotic discs were placed on the surface of MRS agar plates and the plates were incubated at $37^{\circ} \mathrm{C}$ for 24 to $48 \mathrm{hrs}$. Antibiotic susceptibility 
pattern was assessed using, Amphicillin(Amp), Amoxycillin(Amx),Bacitracin(B), Chloromphenicol(C), Clindamycin (Cd), Erythromycin (E), Gentamcin(Gen), Methcillin (Met), Norfloxacin(Nx), Penicillin (P) Streptomycin(S), Tetracyclin(Te), Trimethoprim(Tr) and Vancomycin(V).

\section{Antimicrobial test by Agar well diffusion Method:-}

The agar well diffusion method was used to determine the antimicrobial property of the LAB isolates. The selected LAB isolates were inoculated from slants to fresh $250 \mathrm{ml}$ MRS broth and incubated at $37^{0} \mathrm{C}$ for $24-48 \mathrm{hrs}$. The culture broth of each isolate was centrifuged separately at 10,000 $\times \mathrm{g}$ for 30 minutes. The supernatant was collected after centrifugation and passed through $0.2 \mu \mathrm{m}$ sterile syringe filter. To confirm bacteriocin production, the cell free neutral supernatant broths was collected for the antibacterial study against selected food borne pathogens.

A $24 \mathrm{hr}$ culture of the pathogens such as Bacillus cereus, E.coli, Pseudomonas, S.aureus, Klebsiella and S.typhi grown at $37^{\circ} \mathrm{C}$ was suspended in saline. A lawn of the indicator strain was made by spreading the cell suspension over the surface of nutrient agar plates with a sterile cotton swab. The plates were allowed to dry and a sterile cork borer of diameter $(5 \mathrm{~mm})$ was used to make uniform wells in the agar. Each well was filled with $60 \mu 1$ culture free filtrate obtained from the LAB isolates. After incubation at $37^{\circ} \mathrm{C}$ for $48 \mathrm{hrs}$, the plates were observed for a zone of inhibition (ZOI) around the well. Results were considered positive if the diameter $(\mathrm{mm})$ of the ZOI was greater than $1 \mathrm{~mm}$.

\section{Result and Discussion:-}

Isolation and identification of Probiotic microorganism:-

All the microbial colonies on MRS agar plates were morphologically characterized (Table 1) based on their colony characteristics obtained along with their Gram reaction and microscopic examination. Isolates showing phenotypic characters similar to Lactobacillus species on MRS agar media (LB, LPA, LT, LCB, LMP and LTP) on the basis of above morphological and biochemical features were selected for further experiments. The isolate showing similar morphology and staining characteristic were followed by biochemical tests and sugar utilization tests (Table $\mathbf{2}, \mathbf{3}$ and 4) and some of them confirmed as Lactobacillus spp.

Table 1:- Morphological Characteristics of Lactic Acid Bacteria.

\begin{tabular}{|l|l|l|l|l|l|l|l|}
\hline Samples & Size $(\mathrm{mm})$ & Color & Elevation & $\begin{array}{l}\text { Cultural } \\
\text { characters }\end{array}$ & $\begin{array}{l}\text { Cell } \\
\text { Morph. }\end{array}$ & $\begin{array}{l}\text { Gram } \\
\text { Staining }\end{array}$ & $\begin{array}{l}\text { Endospore } \\
\text { Staining }\end{array}$ \\
\hline LB & 1 & Creamy White & Convex & Moist, Regular & CC & $+\mathrm{Ve}$ & $-\mathrm{Ve}$ \\
\hline LPA & $1-2$ & White & Convex & Moist, Regular & SR & $+\mathrm{Ve}$ & $-\mathrm{Ve}$ \\
\hline LT & $1-2$ & Creamy White & Convex & Moist, Regular & Cc & $+\mathrm{Ve}$ & $-\mathrm{Ve}$ \\
\hline LCB & 1 & Grey white & Convex & Moist, Regular & Cc & $+\mathrm{Ve}$ & $-\mathrm{Ve}$ \\
\hline LMP & $1-2$ & Creamy white & Convex & Moist Regular & Cc & $+\mathrm{Ve}$ & $-\mathrm{Ve}$ \\
\hline LTP & $1-2$ & Creamy white & Convex & Moist Regular & $\mathrm{Cc}$ & $+\mathrm{Ve}$ & $-\mathrm{Ve}$ \\
\hline
\end{tabular}

*SR: Straight Rods; Cc: Cocci; +Ve: Postive; -Ve: Negative

Figure 1:- Isolation of Pure Culture from MRS Plate.

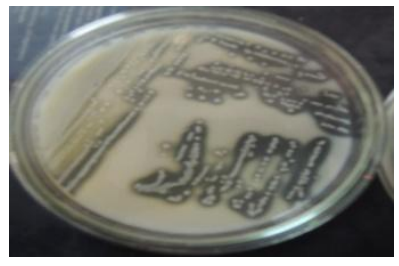

Figure 2:- Gram Staining of LAB.

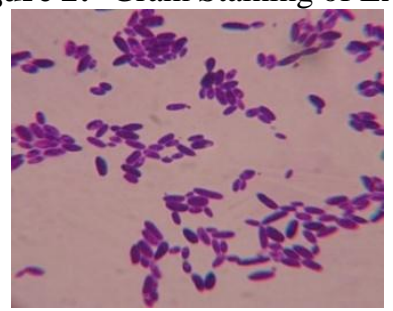


Table 2:- Biochemical Characterization Test of Lactic Acid Bacteria.

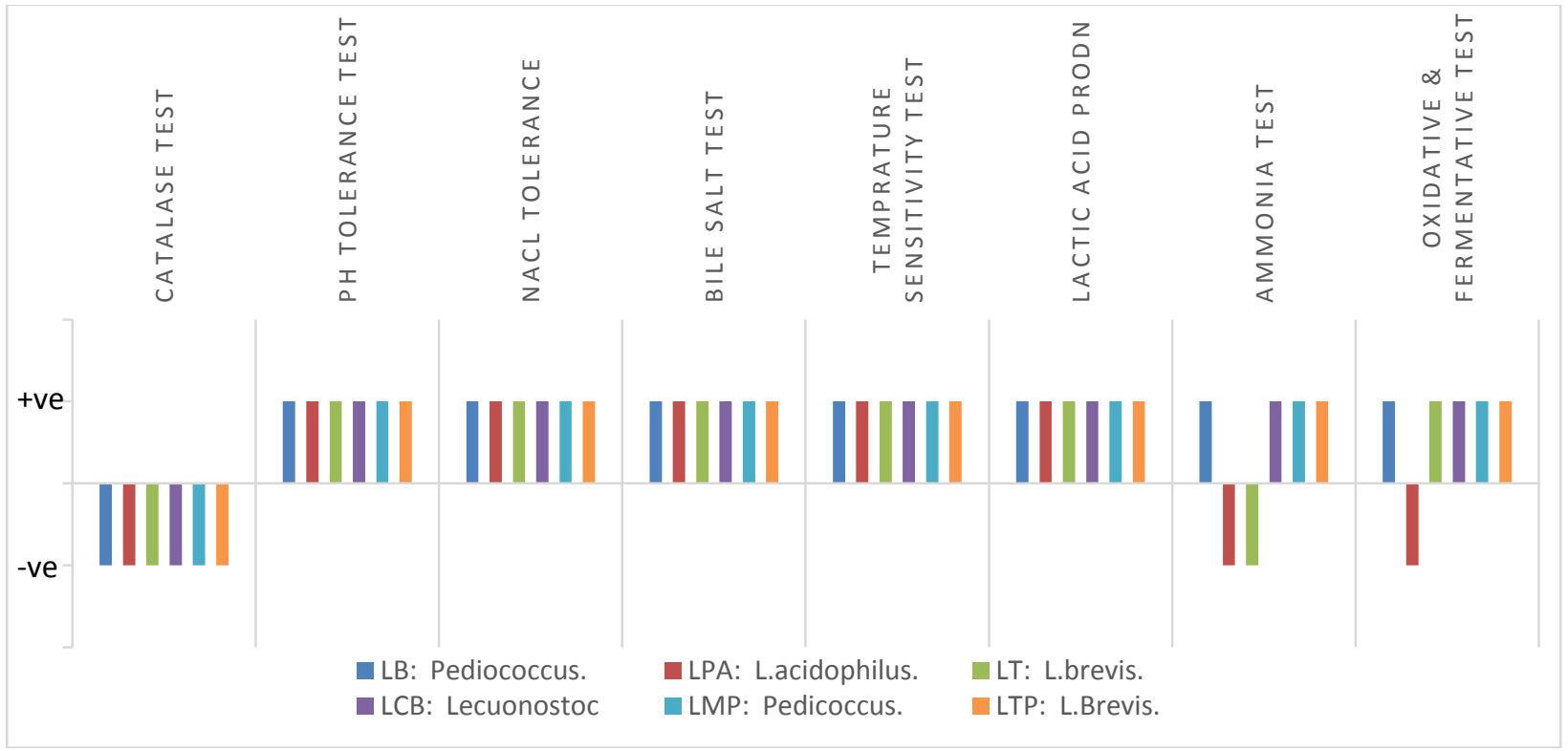

Table 3:- Phenotypic characterization of Lactic Acid Bacteria by Sugar Utilization.

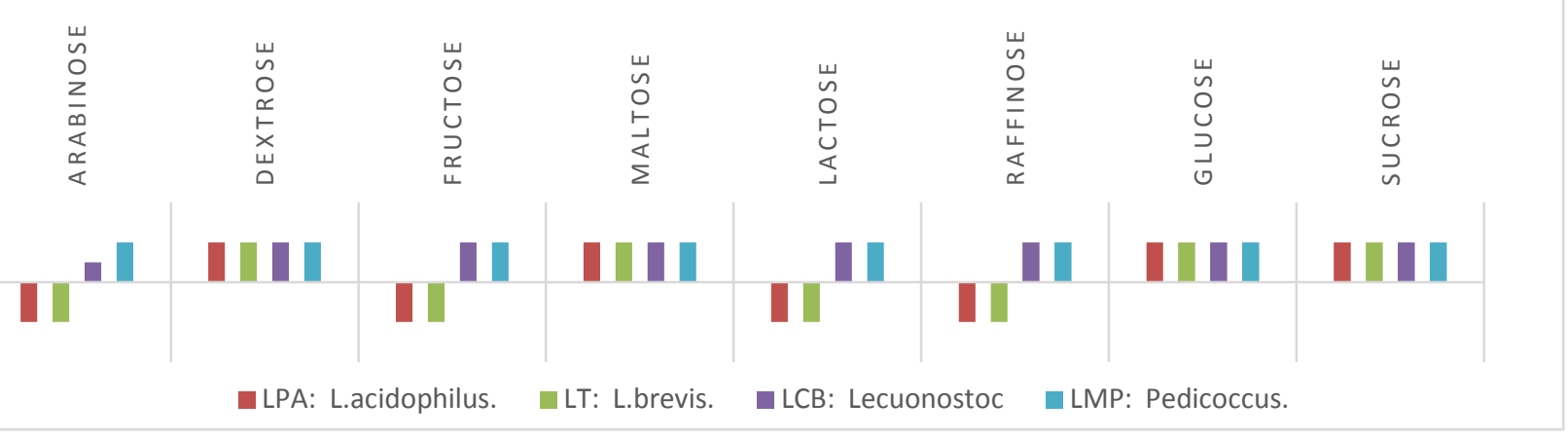

Table 4:- Gas Production by Lactic Acid Bacteria by Sugar Utilization.

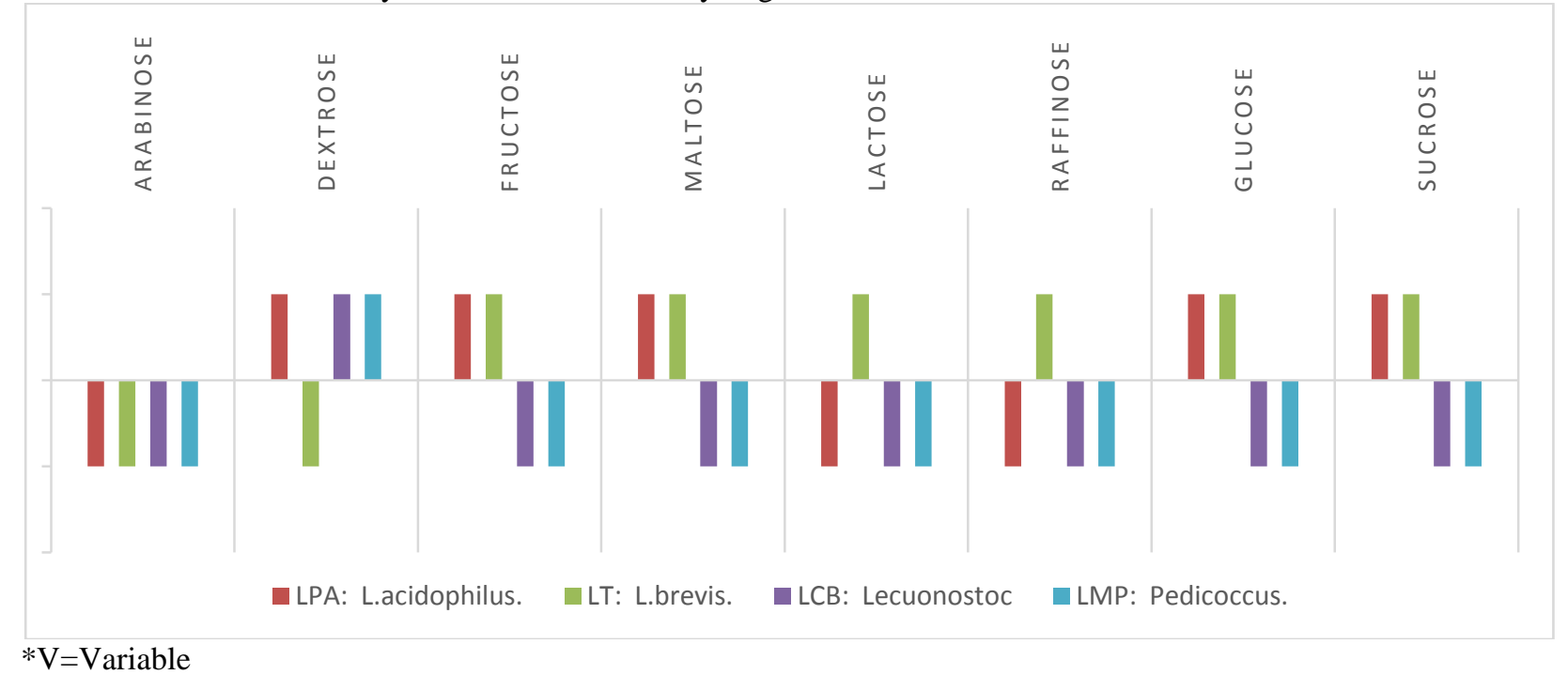

$* \mathrm{~V}=$ Variable 
After performing all the tests strains labeled as LPA, LT, LCB and LMP were identified as Lactobacillus acidophilus, L.brevis, L.leuconostoc and L.pediococcus respectively and these strains were used in further experiments.

\section{Determination of the antimicrobial activity of selected LAB by agar well diffusion Method:-}

The agar well diffusion method was used to assess the antimicrobial activity of the selected LAB namely LPA, LT, LCB, and LMP isolated from varied sources. Their antimicrobial properties were tested against major food-borne pathogenic bacteria namely B.cereus, E.coli, Pseudomonas, S.aureus, Klebsiella, and S.typhi were taken from MTCC. Results show that the spectrum of inhibition was different for the isolates tested. Table 5 gives the results for the antimicrobial activity of the isolates in terms of diameter of the zone of inhibition (ZOI). A diameter $>1 \mathrm{~mm}$ around the well was considered as a positive result. Among all the isolated lactobacillus spp. LMP was found to be showing potent antimicrobial activity against most of the pathogenic organisms.

Table 5:- Antimicrobial Activity of Lactic Acid Bacteria.

Zone of inhibition (in mm)

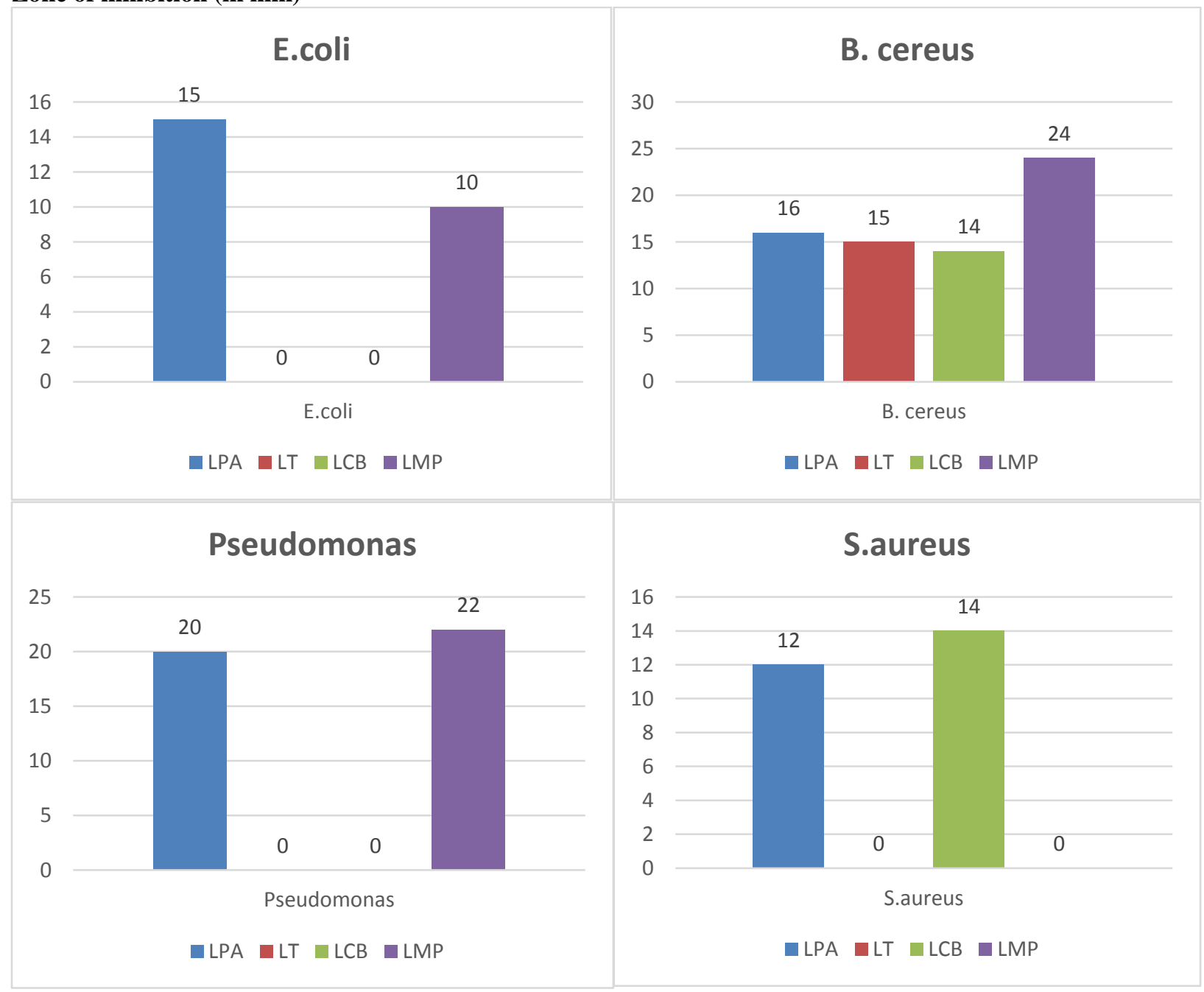




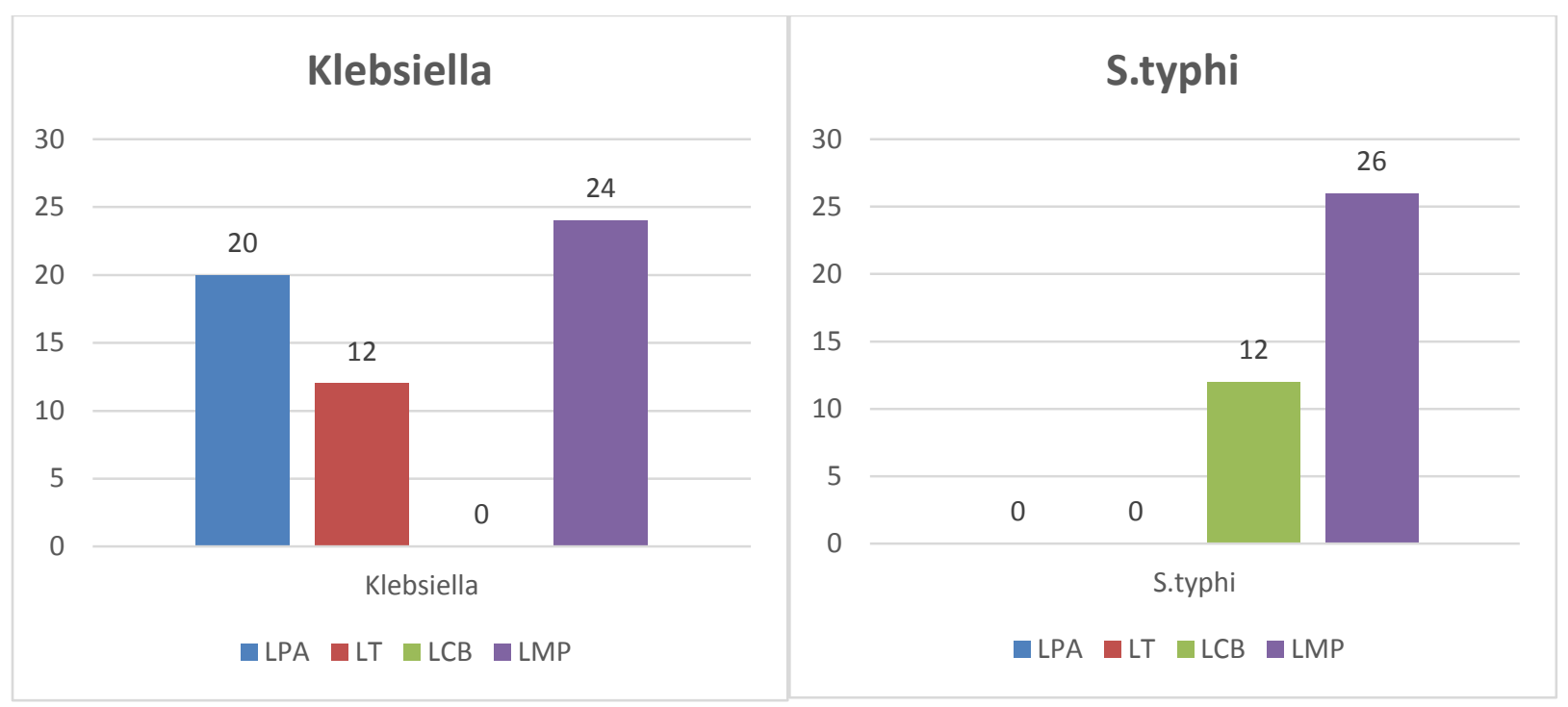

“O”= Resistant

Antibiotic susceptibility Test:-

The overnight grown culture of isolates of the selected LAB namely LB, LPA, LT, LCB, and LMP isolated from varied sources (Lactobacillus spp) were inoculated .Their growth were checked after $48 \mathrm{hrs}$ of incubation at $37^{\circ} \mathrm{C}$. Table 6 shows that the five isolates were resistance to Amphicillin (Amp), Trimethoprim (Tr), and Norfloxacin $(\mathrm{Nx})$. Some of the isolates showed resistance to other antibiotics. The isolates were found resistant to cell wall synthesis inhibitor i.e Penicillin, Vancomycin and protein synthesis inhibitor Gentamicin, Streptomycin but sensitive to tetracycline at higher concentration $200 \mu \mathrm{g} / \mathrm{ml}$ and above.

The results of antibiotic susceptibility test with vancomycin and streptomycin were different from the observation made by Kim et al (8). Hoque et al (7) found that the Lactobacillus spp. is sensitive to Cd, E, Gen, Va, B, C, E, S Amx, Te, Met, and resistant to trimethoprim (Tr), amphicillin (Amp), norfloxacin (Nx). It is possibly because of $\beta$ lactamase presence in the isolate which is known to cause antibiotic resistance towards penicillin and other cell wall synthesis inhibitory compounds. Similar results were also observed by Coppola et al. (9), Lira et al. (10), Caro et al. (11) and Hleba et al (12) where they examined antibiotic resistance of bacteria isolated from various food samples have argued that the results of antibiotic resistance vary from study to study.

Table 6:- Antibiotic Sensitivity of Lactic Acid Bacteria Isolates.

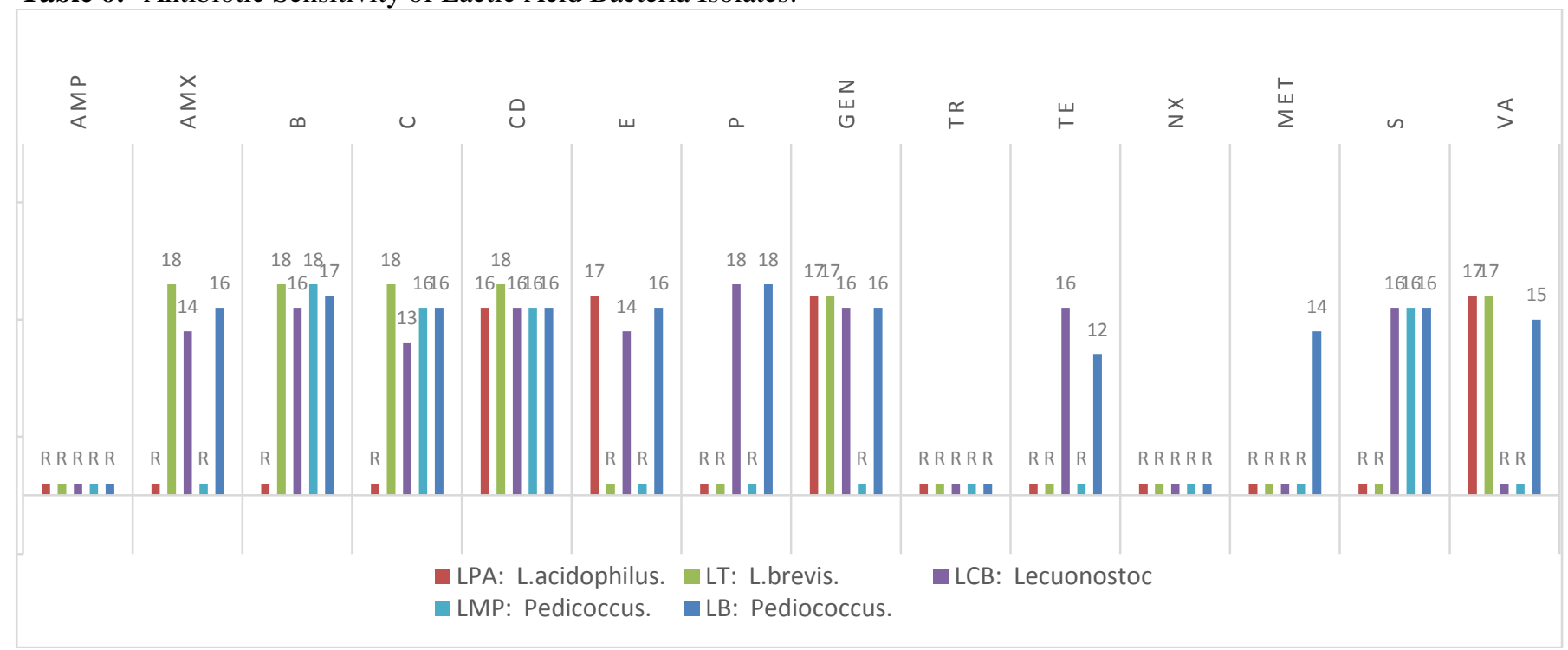

$" R "=$ Resistant. 


\section{Discussion:-}

It is recommended that a human friendly bacterium has been isolated with respect to native food products due to their efficacy. In this current study, we found out that our samples show good amount of probiotic potential microorganism which could be a valuable source to get the probiotic food Products for the future demands. It could be applied in designing starter culture for industrial food production in large scale even for dairy industries to meet the global demand of world market to make healthy lifestyles and prevent modern diseases that the current world suffers from as a result of industrial and urban lifestyles.

\section{Conclusion:-}

The present study was aimed to isolate and characterize probiotic bacteria from different native sources especially from plant sources. Since there is substantial demand for natural food products which can be used for as probiotic food supplements to enrich nutritionally rich diet as well as cure to diseases these as they are very much diversified in gaining importance. As this probiotics impart beneficial properties without any genetic or molecular changes in the health of consumers which is an attractive solution for diseases management through the diet. In general, it is believed that Probiotics help keep up the balance between harmful and beneficial bacteria in the gut thus maintaining a healthy digestive system [13]. The study is extremely promising, that underscores the important role of Lactobacillus strains.

\section{Acknowledgement:-}

I express my deep sense of gratitude and indebtedness to Dr. B. Bhima, Assistant Professor, Department of Microbiology, Osmania University, Hyderabad, for giving me opportunity to carry out my project and for allowing me to do my project work under his supervision in his research laboratory and for helpful discussions, valuable suggestions in all respects for his cooperation and indispensable help in completion of my project work. It is my privilege to thank for his kind support and encouragement. .I also thanks my Lecturers, friends \& well wishers for their moral support and encouragement. I acknowledge with deep appreciation the indispensible aid to Mr. K..Jaganchandra (Executive Director, Integrants BioTech Lab.) for assistance and encouragement .And my Family for their support in enabling me to complete my work.

\section{References:-}

1. Meera, N.S. and Charitha Devi, M. 2012. Partial characterization and optimization of parameters for bacteriocin production by probiotic Lactic acid bacteria. J. Microbiol. Biotech. Res. 2 (2):357-365.

2. Schleifer, K.H. and Ludwig, W. 1995. Phylogenetic relationships of lactic acid bacteria. In: The Genera of Lactic Acid Bacteria, B. J. B. Wood, W. H. Holzapfel (Eds.), Blackie Academic \& Professional, Glasgow. pp. 1 18.

3. Collins, J.K .,Thjorton,G. and Sullivan ,G.O 1998.Selection of probiotic strains for human application.Int Dairy $\mathrm{J} 8,487-490$.

4. Isolauri E, Kirjavainen PV and Salminen S. Probiotics: a role in the treatment of intestinal infection and inflammation? Gut. 2002; 50: 54-59.

5. Dicks LMT and Botes M. Probiotic lactic acid bacteria in gastro-intestinal tract: health benefits, safety and mode of action. Beneficial Microbes. 2010; 1: 11-29.

6. Ouwehand,A.c., Salminen ,S.Tolkko,S.,Roberts, P.,colonic tissue: new model for characterizing adhesion of lactic acid bacteria.Clin Diag Lab Immuno 9,184-186.

7. Gill H, Prasad J, Smart J and Gopal PK. Selection and characterization of Lactobacillus and Bifidobacterium strains for use as probiotic, Int Dairy J.1998; 8: 993-1002.

8. Fuller R. Probiotics: The Scientific Basis. Vol. 1. Chapmann and Hall, US; 1992

9. Saavedra JM. Clinical Applications of Probiotic Agents. Am J Clin Nutr. 2001; 73: 1157S-1151S

10. Medina M, Collins AG, Silberman JD and Sogin ML. Evaluating hypotheses of basal animal phylogeny using complete sequences of large and small subunit rRNA. PNAS. 2001; 98: 9707-12.

11. Sullivan MGO, Thornton G, Sullivan GCO and Collins JK. Probiotic bacteria: myth or reality? Trends Food Sci Technol.1992; 3: 309-314

12. Holt JG, Krieg NR, Sneath JTS and Williams ST. Bergey's manual of Determinative Bacteriology. $9^{\text {th }}$ edn. Williams and Wllkins, London, UK; 1994. 
13. Kim HS, Jeong SG, Ham JS, Chae HS, Lee JM and Ahn CN. Antioxidative and Probiotic Properties of Lactobacillus Gasseri Nlri-312 Isolated From Korean Infant Feces, Asian-Australian J Animal Sci. 2006; 19: $1335-1341$.

14. Hoque MZ, Akter F, Hossain KM, Rahman MS, Billah MM and Islam KMD. Isolation, identification and analysis of probiotic properties of Lactobacillus Spp. from selective regional yoghurts, World J Dairy Food Sci. 2010; 5: 39-46.

15. Coppola R, Succi M, Tremonte P, Reale A, Salzano G and Sorrentino E. Antibiotic susceptibility of Lactobacillus rhamnosus strains isolated from Parmigiano Reggiano cheese. Le Lait. 2005; 85: $193-204$.

16. Lira WM, Macedo C and Marin JM. The incidence of shiga toxin-producing Escherichia Coli in cattle with mastitis. J Appl Microbiol. 2004; 97: 861-866.

17. Caro I, Mateo JG and Armesto MR. Phenotypical characteristics of shigalike toxin Escherichia coli isolated from sheep dairy products. Letter of Appl Microbiol. 2007; 45: 295-300.

18. Hleba L, Kacaniova M, Lejkova J and Pochop J. Antibiotic resistance of Enterobacteriaceae species

19. associated with faecal bacterial cenosis of ducks. Animal Sci Biotechnol. 2011; 44:408-414.

20. Tambekar, D.H. and Bhutada, S.A. An evaluation of Probiotic potential of lactobacillus sp. from milk of domestic animals and commercial available Probiotic preparations in prevention of enteric bacterial infections. Recent Research in Science and Technology.2010; 2: 82-88.

21. Adebayo-tayo, B. C. and Onilude, A. A. Screening of Lactic Acid Bacteria Strains Isolated from Some Nigerian Fermented Foods for EPS Production. World Applied Sciences Journal. 2008; 4: 741-747

22. Ahmed, T. and Kanwal, R. Biochemical characteristics of lactic acid producing bacteria and preparation of camel milk cheese by using starter culture. Pakistan Vet. J. 2004; 24:87-91.

23. Savadago, A., Ouattara C. A. T., Bassole I. H. N. and Traore, S. A. Bacteriocins and lactic acid bacteria - a minireview. African journal of biotechnology. 2006: 5(9): 678-683.

24. Psomas E, et al., Some probiotic properties of yeast isolates from infant feces and feta cheese. .Int. J. Food Microbiol 2001. 69: p. 125-133.

25. Piard J.C and D. M.,Inhibiting factors produced by lactic acid bacteria: Oxygen metabolites and catabolism endproducts, Bacteriocins and other antibacterial substances.Lait 1991. 71: p. 525-541.

26. Gotcheva V, et al., Assessment of potential probiotic properties of lactic acid bacteria and yeast strains. $\mathrm{J}$ Food Biotech., 2002. 16: p. 211-225

27. Lian W.C, Hsiao H.C, and C. C.C., Viability of microencapsulated bifidobacteria in simulated gastric juice and bile solution.Int. J. Food Microbiol., 2003. 86: p. 293-301.

28. Goktepe I, Juneja V.K, and A. M., Probiotics in food safety and human health., ed. B. Raton2006, FL, USA: CRC Press, FL: Taylor and Francis group.

29. Capela P, Hay T.K.C, and S. N.P., Effect of cryoproyectants, prebiotics and microencapsulation on survival of probiotic organisms in yoghurt and freeze-dried yoghurt.Food Res. Int. , 2006. 39: p. 203-211.

30. Salvatierra M, et al., Evaluation of the effect of probiotic cultures on two different yogurt brands over a known population of Staphylococcus aureus and the production of thermonuclease. Arch Latinoam Nutr, 2004. 54: p. 298-302. 